Cakrawala Dini: Jurnal Pendidikan Anak Usia Dini | p-ISSN 2087-I317 | e-ISSN 262I-8321

Vol. S. No.2 November 2018 | Hal 75-87

\title{
PENGEMBANGAN MEDIA MAKET BERBASIS KOTA PALEMBANG UNTUK ANAK
}

\author{
Efi Novitasari ${ }^{1}$, Sri Sumarni, Yetty Rahelly \\ Program Studi Pendidikan Anak Usia Dini Fakultas Keguruan dan Ilmu Pendidikan \\ Universitas Sriwijaya
}

\begin{abstract}
This research aims to produce media maket based palembang city. The development of media model based on Palembang city uses a combination of Rowntree development model and Tessmer evaluation. The Rowntree development model consists of three stages, namely the planning, development and evaluation phase. At the evaluation stage, the formative evaluation proposed by Tessmer consists of five stages: self evaluation, expert review, one-to-one evaluation, small group evaluation. Technique of collecting data using observation. The result of the expert review obtained the average value of the assessment result from the experts in the amount of 3.80 (very valid category), Phase one to one evaluation obtained the average of the results of the observation of children with media maket of $94 \%$ (very good category). Stage small group evaluaion obtained the average result of observation on media maket $96 \%$ (very good category). From all stages that have been done then it can be concluded that the media maket declared valid, practical for child group $B$.
\end{abstract}

Keyword: Media Development, Palembang City, Children Group B

\begin{abstract}
Abstrak: Penelitian ini bertujuan untuk menghasilkan media maket berbasis kota palembang. Pengembangan media maket berbasis kota palembang ini menggunakan kombinasi model pengembangan Rowntree dan evaluasi Tessmer. Model pengembangan Rowntree terdiri dari tiga tahap, yaitu tahap perencanaan, pengembangan dan tahap evaluasi. Pada tahap evaluasi dilakukan evaluasi formatif yang dikemukakan oleh Tessmer terdiri dari lima tahap, yaitu tahap self evaluation, expert review, one-to-one evaluation, small group evaluation. Teknik pengumpulan data menggunakan observasi. Hasil expert review diperoleh nilai rata-rata hasil penilaian dari para ahli pada 1 sebesar 3.80 (kategori sangat valid), Tahap one to one evaluation didapatkan rata-rata hasil observasi anak dengan media maket sebesar $83 \%$ (kategori baik sekali).Tahap small group evaluaion didapatkan hasil rata-rata observasi pada media maket $86 \%$ (kategori baik sekali). Dari semua tahap yang telah dilakukan maka dapat disimpulkan bahwa media maket dinyatakan valid, praktis untuk anak kelompok B.
\end{abstract}

Kata Kunci: Pengembangan Media, Kota Palembang, Anak Kelompok B

\section{PENDAHULUAN}

Pada awal sejarah pendidikan, guru merupakan satu-satunya sumber untuk memperoleh pelajaran dalam perkembangan selanjutnya sumber belajar kemudian bertambah dengan adanya buku (Aqib, 2016:49). Pada proses pembelajaran, media pengajaran merupakan wadah dan penyalur pesan dari sumber pesan, dalam hal ini guru kepada penerima pesan yaitu siswa. Dalam batasan yang lebih luas, Yusufhadi (2012:27) Memberikan batasan media pengajaran sebagai segala sesuatu yang dapat digunakan untuk merangsang pikiran,perasaan, perhatian, dan kemauan siswa sehingga mendorong terjadinya proses belajar pada diri siswa.

Penggunaan media pembelajaran dapat membantu pencapaian keberhasilan

'Universitas Sriwijaya, Email: efinavitasariz2回gmail.com 
belajar. Menurut Danim dikutip Mahnun (2012:27) bahwa hasil penelitian telah banyak membuktikan efektivitas penggunaan alat bantu atau media dalam proses belajar-mengajar di kelas, terutama dalam hal peningkatan prestasi siswa, Terbatasnya media yang dipergunakan dalam kelas diduga merupakan salah satu penyebab lemahnya mutu belajar siswa. Pada proses pembelajaran media merupakan wadah penyalur pesan dari sumber pesan ke penerima pesan guru sebagai Penyalur pesan dan murid sebagai Penerima Pesan.

Berdasarkan hasil observasi Analisis di TK Bkhati Asuhan 1,TK IT Darusalam,dan TK Aliyati Palembang, Ketiga TK tersebut masih menggunakan media Pembelajaran berupa gambar yang di Print di kertas A4. selain menggunakan gambar guru juga menggunakan media buku pada kegiatan pembelajaran anak hanya melakukan kegiatan mewarnai gamabar menulis huruf kata Ikan belida, Monpera dan sebagainya sehingga kegiatan pembelajaran menjadi monoton. Anak-anak menjadi kurang fokus terhadapa pembelajaran karena keterbatasan kegunaan media.sehingga dibutuhkan media yang inovatif, kreatif media tersebut juga multi fungsi bisa digunakan sebagai media pembelajaran dan bisa juga dijadikan alat permainan oleh anak.

Hasil observasi dan analisis media hanya melibatkan satu pihak yaitu observer, saya selaku obsever telah melakukan analisis media, saya melakukan wawancara dengan guru yang ada di kelas. Di TK Bhakti Asuhan 1 saya mewawancarai ibu husnita selaku guru kelas B3,di TK IT Darusalam saya mewawancarai ibu Afrida selaku guru di Kelas B4 dan di TK Aliyati saya mewawancarai Ibu Yanti selaku guru Kelas B2. hasil wawancara dengan tiga TK tersebut membuktikan bahwa media untuk pembelajaran tentang kota Palembang masih kurang hanya menggunakan gambar prinan dikertas A4.
Untuk mendukung pembelajaran pada anak usia dini agar terlaksana dengan baik maka diperlukanya media yang baik, media tersebut harus berbasis Kota Palembang yang konstruktif/bersifat membangun dan Media harus dapat membuat anak belajar secara aktif, inovatif, efektif, dan menyenangkan. Tentunya media harus berorientasi pada perkembangan anak. Sesuai dengan teori tersebut bahwa penggunaan dirasa tepat akan tetapi dari berbagai media salah satu yang tepat untuk mengajarkan tanah air ku adalah media berbentuk Maket.

Menurut Rivai dikutip Rusdi (2015:72) Maket adalah tiruan tiga dimensional dari beberapa objek nyata yang terlalu besar, terlalu jauh, terlalu kecil terlalu mahal, terlalu jarang, atau terlalu ruwet untuk dibawa ke dalam kelas dan dipelajari siswa dalam wujud aslinya. Bentuk maket yang akan digunakan adalah maket berbnetuk icon dari kota palembang. Melalui penggunaan maket siswa dapat secara langsung melihat icon kota palembang yaitu Ikan Belido. maket tersebut siswa menjadi tertarik dan mempunyai rasa ingin tahu yang lebih untuk mengikuti pelajaran sehingga antusias dalam mengikuti pelajaran karena maket atau yang biasa dikenal media tiga dimensi dapat memberikan gambaran secara nyata sehingga siswa tidak bosan dalam mengikuti pelajaran dan secara tidak langsung akan menjadikan siswa lebih faham tentang materi yang disampaikan guru dan juga akan mempengaruhi prestasi belajar siswa.

Senada dengan penelitian yang pertama yang dilakukan oleh Sari (2014), memberikan kesimpulan Hasil penelitian menunjukkan bahwa melalui media maket dapat meningkatkan keterampilan berbicara anak kelompok A TK Pembina Cawas Klaten dari prasiklus ke siklus I, dari siklus I ke siklus II. Skor rata-rata keterampilan berbicara anak pada prasiklus adalah 2,55 yakni sebesar $34,61 \%$ atau 9 anak yang mencapai 
kriteria tuntas. Peningkatan terjadi pada siklus I skor rata-rata keterampilan berbicara anak mencapai 3 yakni sebesar $57,69 \%$ atau 15 anak yang mencapai nilai tuntas. Dilanjutkan ke siklus II skor ratarata 3,44 yakni sebesar $80,76 \%$ atau 21 anak yang mencapai nilai tuntas. Simpulan penelitian ini adalah melalui media maket dapat meningkatkan keterampilan berbicara pada anak kelompok A TK Pembina Cawas Klaten. Pada pemaparan dari penelitian diatas maka peneliti tertarik untuk menindak lanjuti penelitian diatas dengan judul “ Pengembangan Media Maket Berbasis Kota Palembang Untuk Anak Kelompok B di TK Bhakti Asuhan 1 Palembang", Untuk mendukung pembelajaran pada anak usia dini agar terlaksana dengan baik maka diperlukannya media interaktif (Ahmadi 2014; Hartati, 2016; Daryanto, 2016; Satrianawati, 2018), model pembelajaran (Istianti, et al, 2018) aplikasi (Afrianti, 2017), buku (Enggar, 2015; Rosidah, 2017)) dan Maket.(Hasnunidah, 2014; Sari, 2014; Putri, 2014; Suciati, 2016; Qo'niah, 2017) yang baik, media misalnya dalam hal ini harus berbasis Kota Palembang yang konstruktif/bersifat membangun dan Media harus dapat membuat anak belajar secara aktif, inovatif, efektif, dan menyenangkan. Tentunya media harus berorientasi pada perkembangan anak. Sesuai dengan teori tersebut bahwa penggunaan dirasa tepat akan tetapi dari berbagai media salah satu yang tepat untuk mengajarkan materi Kotaku adalah media berbentuk Maket.(Hasnunidah, 2014) Bentuk maket yang akan digunakan adalah maket berbnetuk icon dari kota palembang. Melalui penggunaan maket siswa dapat secara langsung melihat icon kota palembang yaitu Ikan Belido maket tersebut siswa menjadi tertarik dan mempunyai rasa ingin tahu yang lebih untuk mengikuti pelajaran sehingga antusias dalam mengikuti pelajaran karena maket atau yang biasa dikenal media tiga dimensi dapat memberikan gambaran secara nyata sehingga siswa tidak bosan dalam mengikuti pelajaran dan secara tidak langsung akan menjadikan siswa lebih faham tentang materi yang disampaikan guru dan juga akan mempengaruhi prestasi belajar siswa.

\section{METODOLOGI PENELITIAN}

Penelitian ini menggunakan motodologi Research Development jenis penelitian yang digunakan oleh Peneliti adalah jenis penelitian dan pengembangan (RD) model yang digunakan adalah model Rowntree karena model ini mengarah ke Pengembangan Produk. Subjek dalam Penelitian ini peserta didik Kelompok B Tk Bhakti Asuhan 1 Palembang Pada semester genap tahun ajaran 2017/2018. objek dalam penelitian ini adalah media maket berbasis kota palembang yang melalui tahap uji coba one to one 3 orang peserta didik untuk uji perorangan, 9 Orang peserta didik untuk uji kelompok kecil, dan 15 orang peserta didik untuk uji coba lapangan. Penelitian ini dilakukan Di TK Bhakti Asuhan $1 \mathrm{Jln}$ Ariodillah Komplek Perumahan No.4551 Palembang pada anak kelompok B disemester genap pada tahun ajaran 2017/2018.

\section{Prosedur Penelitian}

Prosedur penelitian pengembangan ini untuk menghasilkan dan menguji produk menggunakan model ROWNTREE Dalam Mengembangakan Media Pembelajaran. Prosedur penelitian ini menggunakan 3 tahap Berikut ini adalah langkah-langkah model ROWNTREE evaluasi formatif Tessmer:

\section{Perencanaan Dan Perkembangan Anak Analisis Kebutuhan Anak}

Persiapan dan analisis adalah
tahap yang paling awal dalam
Perancanaan. Pada tahap ini yang
dilakukan penulis adalah mempersiapkan
dari menganalisis apa yang dibutuhkan
peserta didik dalam pengenalan Maket
kota Palembang.Analisis yang dilakukan


terdiri dari dua macam, yaitu: analisis media dan wawancara.

\section{Pengembangan}

\section{Analisis Media Pembelajaran}

Pada tahap inipeneliti melakukan analisis terhadap media pembelajaran yang menjadi objek dalam penelitian untuk mengenalkan maket berbasis kota palembang, analisis ini bertujuan untuk mengetahui bagaimana pengenalan terhadap media maket terhadap siswa di 3 Tk Bhakti Asuhan 1, TK IT Darusalam,TK Pertiwi. Penelitin Pendahuluan ini dimulai dari tanggal 12Februari 2018. Dari hasil analisis peneliti,pada TK Bhakti Asuhan 1 Palembang media yang digunakan untuk mengenalkan icon kota palembang berupa gambar sedrhana yang di cetak oleh guru sendiri,selain TK Bhakti Asuhan TK Darusalam dan TK Pertiwi ketika mengenalkan ikan belida mereka menggunakan media berupa media gambar hal ini membuat siswa tidak dapat berkreasi secara langsung menggunkan media.

\section{Analisis Wawancara}

Tahap selanjutnya adalah mewawancarai guru kelas di 3 TK yang peneliti Pertanyaan yang peneliti ajukan terhadap guru yakni seputar media yang digunakan pada saat mengenalkan icon kota palembang, masalah apa saja yang sering dihadapi oleh guru dalam penyampaian materi, masalah apa saja yg sering dihadapi anak pada saat pembelajaran berlangsung, apakah media yang digunakan sudah dirasa tepat untuk mengenalkan icon kota palembang ikan belido tersebut serta apakah perlu dikembangakan sebuah media maket yang bisa dibongkar pasang, dari hasil wawancara diakui guru bahwa masalah pada saat menjelaskan materi guru masih banyak membutuhkan berbagai macam media untuk mejleskan materi.kemudian masalah yang biasa dihadapi anak saat belajar yaitu, konsentrasi anak sering tidak fokus pada saat pembelajaran karena keterbatasan media.

Media yang dgunakan masih banyak kekurangan sehingga perlu dikembangkan suatu media yang menarik sehingga anak lebih termotivasi dalam pembelajaran khususnya untuk belajar tentang icon kota palembang pada tema tanah air sub tema kota. Media maket berbasis kota palembang perlu dikembangkan karena menugurut hasil wawancara terhadap guru karena media pembelajaran maket belum pernah ada disekolah tersebut dikarenakan guru hanya menjelaskan menggunakan gambar yang dicetak dikertas A4. Media maket berbasis kota palembang ini bisa juga diotak atik disusun sehingga anak lebih bersemanagat belajar dan pengetahuan anak lebih bertambah.

\section{Produksi Prototipe}

Setelah membuat desain, langkah selanjutnya adalah memproduksi prototipe. desain yang telah disusun kemudian akan diilustrasikan dalam bentuk asli.

Gambar hasil ilustrasi dari cerita kemudian akan diberikan penjabaran atasnya yang disajikan dalam bentuk cerita yang berisi pengenalan tentang angkaangka, bentuk, ukuran, maupun lambang bilangan sehingga prototipe bisa dikatakan sebagai cerita matematika. Dalam hal ini peneliti akan mengembangkan sebuah produk berupa maket berbasis kota palembang. Maket kota berbasisis kota palembang ini disesuaikan dengan tema yang ada di semester dua. Hasil dari keseluruhan tahap pengembangan ini disebut Prototipe 1.

\section{Evaluasi}

Pada tahap ini, Protipe 1 hasil desain awal akan dievaluasi dengan mengikuti prosedur evaluasi formatif dari tesmer dengan langkah-langkah sebgai berikut:

\section{Self Evaluation}

Pada tahap ini penilaian dilakukan oleh peneliti sendiri terhadap sebuah produk berupa Media Maket Berbasis Kota Palembang yang telah dikembangkan. 
Disini peneliti mengevaluasi sendiri semua Media dalam hal ini adalah Bentuk yang telah dikembangkannya, apakah bentuknya sudah sesuai dan jelas, dari segi warna menarik dan apakah sesuai dengan konsep pembelajaran untuk anak usia 5-6 tahun.

\section{Expert Review}

Validasi ahli yaitu seorang ahli melakukan review terhadap media pembelajaran masih dalam rancangan untuk menentukan kelebihan dan kekurangannya.Proses valiadasi dilakukan oleh tenaga ahli yang sudah berpengalaman untuk menilai dan mengevaluasi valid dan praktisnya suatu Media berupa Maket Berbasis Kota Palembang, untuk memperoleh hasil maksimal mengenai desain media tersebut. lembar validasi digunkan sebagai alat pengumpul data yang diberikan kepada ahli. Kemudian di isi oleh ahli data yang dihasilkan dari ahli tersebut akan digunakan sebagai acuan.

\section{One-To-One Evaluation}

Pada langkah ini peneliti melakukan uji coba media kepada anakanak sebanyak 3 orang untuk mewakili.Anak tersebut diberikan pembelajaran dengan prpotipe 1 yang sudah direvisi.Pada saat proses pemebelajaran anak akan diobservasi melalui lembar observasi yang telah disediakan untuk melihat dan menilai secara langsung tingkah laku atau proses terjadinya suatu pembelajaran dengan menggunakan protiv 1.hal ini dilakukan dengan tujuan melihat kepraktisan Maket tersebut dari sudut pandang anak.

\section{Small Group Evaluation}

Pada tahap ini protive 2 diuji cobakan pada kelompok kecil anak yang terdiri dari 9 orang. Selanjutnya,anak diberikan pembelajaran dengan protipe 2 . Yang sudah direvisi. pada proses pembelajaran,anak akan diobservasi kembali untuk melihat dan menilai secara langsung tingkah laku atau proses terjadinya suatu pembelajaran dengan menggunakan Media Maket berbasis Kota Palembang (Proipe 2) yang digunakan.

\section{Teknik Pengumpulan Data}

Teknik Pengumpulan data dilakukan dengan cara Waltrought, Observasi.

Walkthrough dikutip Anggraini (2015) adalah validasi data yang melibatkan beberapa ahli untuk mengevaluasi produk sebagai dasar untuk merevisi produk awal/prototipe 1. Instrumen pengumpul data pada teknik ini adalah dengan menggunakan lembar validasi yang diberikan kepada ahli atau validator. Data yang dikumpulkan pada lembar validasi ini adalah berupa tanggapan dan saran-saran yang menjadi dasar peneliti untuk melakukan revisi pada produk awal/prototipe . Data dari hasil validasi oleh ahli kemudian didiskusikan dengan ahli itu sendiri untuk mendapatkan kejelasan informasi hasil validasi produk, sehingga peneliti bisa menggunakan data hasil validasi tersebut sebagai acuan untuk merevisi produk/prototipe sampai dinyatakan layak untuk diujicobakan. Dalam buku cerita matematika, proses validasi ahli meliputi validasi materi dan media.

Tabel 1 Kisi-Kisi Instrumen Validasi Content/Materi

\begin{tabular}{|l|l|c|}
\hline No & $\begin{array}{l}\text { Indikator/aspek } \\
\text { yang dinilai }\end{array}$ & Deskriptor \\
\hline 1 & $\begin{array}{l}\text { Kriteria Materi } \\
\text { Pada Media }\end{array}$ & 1 \\
\hline 2 & $\begin{array}{l}\text { Kesesuai dengan } \\
\text { pembelajaran } \\
\text { anak usia 5-6 } \\
\text { tahun }\end{array}$ & 2 \\
\hline 3 & $\begin{array}{l}\text { Kesesuain } \\
\text { dengan } \\
\text { kebutuhan dan } \\
\text { perkembangan } \\
\text { anak usia 5-6 } \\
\text { tahun }\end{array}$ & 3 \\
\hline 4 & Manfaat Media & 4 \\
\hline
\end{tabular}

Tabel 2 Kisi-Kisi Instrumen Validasi Desain

\begin{tabular}{|c|c|c|}
\hline \multicolumn{3}{|c|}{ Media } \\
\hline 1 & $\begin{array}{l}\text { Indikator/aspek } \\
\text { yang dinilai }\end{array}$ & Deskriptor \\
\hline
\end{tabular}




\begin{tabular}{|c|c|c|}
\hline 2 & Tampilan Maket & 2 \\
\hline 3 & $\begin{array}{c}\text { Keamanan } \\
\text { Maket }\end{array}$ & 3 \\
\hline 4 & Ilustrasi Maket & 4 \\
\hline
\end{tabular}

\section{Observasi}

Observasi merupakan suatu proses yang kompleks,suatu proses yang tersusun dari pelbagni proses biologis dan psikologis Sugiono (2017).Pada penelitian ini untuk mendapatkan data observasi dilakukan dengan cara melihat dan menilai secara langsung aktivitas dan tingkah laku anak selama proses pembelajaran dengan menggunakan Media maket Berbasis Kota Palembang.Observasi dilakukan pada Saat One-To-One,small group,dan field test sudah terlaksnakan dengan baik saat menggunakan media maket berbasis kota palembang.

Hasil observasi dicatat oleh Peneilti pada lembar observasi yang telah disediakan dengan kisi-kisi yang dapat dilihat dilihat Pada tabel 3 Dibawah ini.

Tabel 3 Kisi-Kisi Instrumen Observasi Penilaian Aktivitas Anak Terhadap Penggunaan Media Maket Berbasis Kota Palembang

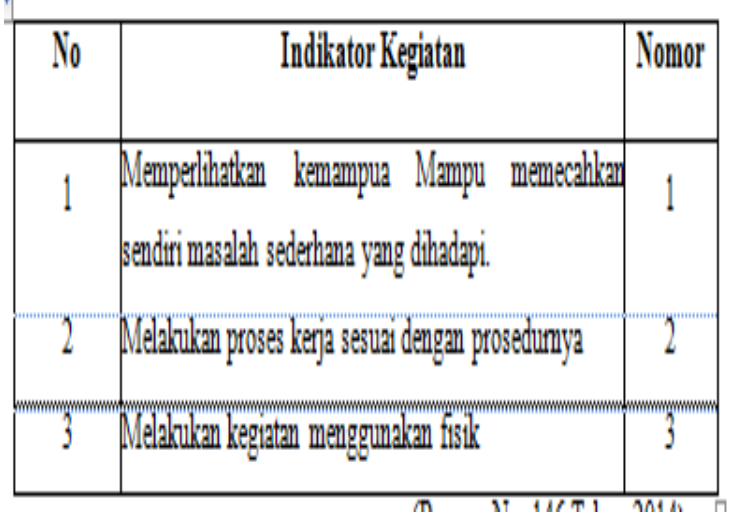

(Permen No. 146 Tahun 2014)

\section{Teknik Analisis Data Analisis Data Waltrought}

Hasil Analisis Data waltrought dengan ahli dianalisis secara deskritif sebagai masukan untuk merivisi Media maket.Masukan tersebut dituliskan pada lembar validas. Lembar validasi yang diberikan kepada ahli dalam bentuk skala likert (Sugiyono,2016:165). Skala Likert Sangat Baik(SB),Baik(B), Tidak Baik(TB),Sangat Tidak baik(STB).

Tabel 4 Kategori Nilai validasi

\begin{tabular}{|c|c|}
\hline Kategori Jawaban & $\begin{array}{c}\text { Skor } \\
\text { Pernyataan }\end{array}$ \\
\hline Sangat Baik & 4 \\
\hline Baik & 3 \\
\hline Tidak Baik & 2 \\
\hline Sangat Tidak Baik & 1 \\
\hline Hasil validasi dari validator
\end{tabular}
disajikan dalam bentuk tabel. Selanjutnya dicari rata-rata skor tersebut dengan menggunakan rumus sebagai berikut.

$$
\mathrm{X}=\frac{\sum X}{N}
$$

Ket :

$\mathrm{X}=$ Nilai rata-rata

$\sum X \quad=$ Jumlah nilai data

$\mathrm{N} \quad=$ Banyaknya da

Selanjutnya rata-rata yang didapatkan disesuaikan dengan kategori seperti yang terlihat pada Tabel 5 berikut ini.

Tabel 5 Kategori Tingkat Kevali dan Gambar

\begin{tabular}{|l|l|}
\hline Rata-Rata & Kategori \\
\hline $3,25-4,00$ & Sangat Valid \\
$2,50-3,24$ & Valid \\
$1,75-2,49$ & Tidak Valid \\
$1,00-1,74$ & Sangat Tidak \\
& Valid \\
\hline
\end{tabular}

\section{Analisis Data Observasi}

Hasil observasi terhadap anak selama ujicoba pada tahap one-to-one evaluation, small group evaluation dan field test digunakan untuk melihat tingkah laku anak pada saat proses pembelajaran menggunakan media maket. Data hasil obsevasi disajikan dalam bentuk tabel, kemudian menghitung nilai hasil observasi dengan 
menggunakan rumus sebagai berikut

Nilai Persentase

$=\frac{\text { Skor Perolehan }}{\text { Skor Maksimal }}$ x $100 \%$

(Sunarti \& Rahmawati, 2014: 191)

Nilai observasi dikonversikan ke dalam kategori yang ditetapkan seperti pada Tabel 3.5

Tabel 6 Kategori Nilai Hasil Observasi Anak Terhadap Penggunaan Media Maket berbasis

\begin{tabular}{|c|c|}
\hline \multicolumn{2}{|c|}{ Kota Palembang } \\
\hline Skor (\%) & Kategori \\
\hline $80-100$ & Sangat \\
$70-79$ & Praktis \\
$60-69$ & Praktis \\
& Cukup \\
$<60$ & Praktis \\
& Kurang \\
& Praktis \\
\hline
\end{tabular}

(Amirono \& Daryanto, 2016: 126)

\section{HASIL PENELITIAN DAN PEMBAHASAN}

Hasil penelitian yang berjudul pengembangan media maket berbasis kota palembang dilakukan dengan tiga tahap yaitu perencanaan, pengembangan,dan evaluasi. peneliti mengambangkan satu buah media. berikut ini adalah uraian tahapan dalam pengembangan media maket berbasis kota palembang.

Persiapan dan analisis adalah tahap yang paling awal dalam Perancanaan. Pada tahap ini yang dilakukan penulis adalah mempersiapkan dari menganalisis apa yang dibutuhkan peserta didik dalam pengenalan Maket kota Palembang.Analisis yang dilakukan terdiri dari dua macam, yaitu: analisis media dan wawancara.

Pada tahap ini peneliti melakukan analisis terhadap media pembelajaran yang menjadi objek dalam penelitian untuk mengenalkan maket berbasis kota palembang,analisis ini bertujuan untuk mengetahui bagaimana pengenalan terhadap media maket terhadap siswa di 3 Tk Bhakti Asuhan 1, Tk IT Darusalam, Tk Pertiwi. Penelitin Pendahuluan ini dimulai dari tanggal 1-3 Februari 2018. Dari hasil analisis peneliti, pada Tk Bhakti Asuhan 1 Palembang media yang digunakan untuk mengenalkan icon kota palembang berupa gambar sederhana yang di cetak oleh guru sendiri, selain Tk Bhakti Asuhan Tk Darusalam dan Tk Pertiwi ketika mengenalkan ikan belida mereka menggunakan media berupa media gambar hal ini membuat siswa tidak dapat berkreasi secara langsung menggunakan media.

Tahap selanjutnya adalah mewawancarai guru kelas di $3 \mathrm{Tk}$ yang diteliti Pertanyaan yang peneliti ajukan terhadap guru yakni seputar media yang digunakan pada saat mengenalkan icon kota palembang, masalah apa saja yang sering dihadapi oleh guru dalam penyampaian materi,masalah apa saja yg sering dihadapi anak pada saat pembelajaran berlangsung, apakah media yang digunakan sudah dirasa tepat untuk mengenalkan icon kota palembang ikan belido tersebut serta apakah perlu dikembangakan sebuah media maket yang bisa dibongkar pasang,dari hasil wawancara diakui guru bahwa masalah pada saat menjelaskan materi guru masih banyak membutuhkan berbagai macam media untuk menjelaskan materi.kemudian masalah yang biasa dihadapi anak saat belajar yaitu,konsentrasi anak sering tidak fokus pada saat pembelajaran karena keterbatasan media.

Media yang dgunakan masih banyak kekurangan sehingga perlu dikembangkan suatu media yang menarik sehingga anak lebih termotivasi dalam pembelajaran khususnya untuk belajar tentang icon kota palembang pada tema tanah air sub tema kota. Satrianawati (2018:7) mengemukakan dalam kegiatan 
pembelajaran guru harus mencari, memilih, dan menggunakan sumber belajar dan media yang tepat sesuai dengan tujuan dan materi pembelajaran tersebut. Media maket berbasis kota palembang perlu dikembangkan karena menugurut hasil wawancara terhadap guru karena media pembelajaran maket belum pernah ada disekolah tersebut dikarenakan guru hanya menjelaskan menggunakan gambar yang dicetak dikertas A4. Media maket berbasis kota palembang ini bisa juga diotak atik disusun sehingga anak lebih bersemanagat belajar dan pengetahuan anak lebih bertambah.

Kegiatan pada tahap ini dimulai dengan merancang produk media maket berbasis kota palembang berbahan kayu.sesuai dengan katar anak-anak PAUD maka media maket berbasis kota palembang ini harus aman sehingga tidak membahayakan bagi anak.Ide untuk bahan dasar kayu didapat pada saat melakukan P4 di sebuah Tk,dimana siswa-siswa tersebut banyak sekali yang bermain balok kayu.Maket berbasis kota palembang didesain berbentuk tugu ikan belida yang dapat dibongkar pasang,dimana ide ini bermulai dari banyaknya anak-anak yang bermain mainan lego bongkar pasang.Senada dengan Trianto (2013:21) mengemukakan bahwa guru dapat menciptakan suatu keadaan atau lingkungan belajar yang memadai agar siswa dapat menemukan pengalaman nyata dan terlibat langsung denganalat dan media. Berangkat dari hal ini penulis kemudian mencoba menerapkan pada siswa di Tk bahkti Asuhan tersebut dan berhasil. Penulis berfikir apabila balok kayu dimodikfikasi menjadi sebuah media yang bisa diongkar pasang dengan bentuk ikan belido dikemas dengan sebaik-baiknya maka benda tersebut akan bermanfaat bagi anak-anak Tk.

Langkah-langkah pembuatan maket berdasarkan bahannya Cara membuat model/maket dari bahan kayu adalah sebagai berikut. (1).Kumpulkan gambar atau foto yang akan dijadikan model. (2) Pelajari detail gambar tersebut kemudian buat sktesanya. (3). Vatatlah strukturnya secara cermat dan teliti. (4). Siapkan bahan utama berupa kayu. Untuk kayu yang digunakan dalam pembuatan model/maket disarankan kayu yang lunak, jadi mudah dikerjakan, Misalnya dipotong, ditatah, dibor, dan dipaku. Contoh kayu lunak yaitu : Pinur putih ,kayu merah atau kayu ara dan kayu biasa. Jenis terakhir ini paling banyak ditemukan di toko-toko kerajinan tangan dan ditempat penyimpanan kayu.Sementara contoh kayu kertas, yaitu mahoni. (5). Untuk bahan tambahan yang dibutuhkan,seperti kawat,cat atau zat perwarna dan tali rafia. Sementara alat yang perlu disipakan yaitu,pisau,gunting,palu,paku,gergaji,kua s,tang,lem,kayu,plester dan obeng. (6). Potong kayu sesuai sket model ynag telah kita buat.(7). Sambung dan letakan kayu(yang telah dipotong menurut struk nya.) dengan paku atau alat perekat lainnya. (8). Berikan pewarna dengan pengecatan untuk menambahkan kesan asli kepada model. (9). Siapkan informasi pendukung dalam selembar kerta tentang model tersebut. (10). Berikan tugas yang berkenaan dengan model kepada siswa,dapat secara lisan atau tertulis. (11). Lakukanlah penilaian terhadap jawabn yang diberikan siswa dengan kriteria telah kita tetapkan.

Setelah membuat desain, langkah selanjutnya adalah memproduksi prototipe. desain yang telah disusun kemudian akan diilustrasikan dalam bentuk asli. Gambar hasil ilustrasi dari desain gambar kemudian akan dibuat yang disajikan dalam bentuk maket berbasis kota palembang. setelah dibentuk menyerupai tugu ikan belida kemudia maket tersebut diwarani dengan cat warna sesuai dengan warna tugu ikan belida asli. Dalam hal ini peneliti akan mengembangkan sebuah produk berupa maket berbasis kota palembang. seperti 
yang dikemukakan dayanto dikutip oleh Hasnunidah (2014) KeuntunganKeutungan menggunakan media tiruan adalah belajar dapat difokuskan pada bagaian yang penting-penting saja dapat menunjukan struktur objek, serta siswa memperoleh pengalaman yang konkrit. Maket kota berbasis kota palembang ini disesuaikan dengan tema yang ada di semester dua. Hasil dari keseluruhan tahap pengembangan ini disebut Prototipe 1 .

Expert review yaitu tahap untuk melihat validitas secara content atau materi dan desain media maket berbasis kota palembang yang dikembangkan oleh peneliti. Tahap ini bertujuan untuk mendapatkan materi dan desain media maket valid. Dalam proses validasi peneliti menggunakan metode walktroug, yaitu setiap lembar prototype diberikan kepada pakar dan setiap lembar prototype tersebut divalidasi. Para pakar/ahli yang menjadi validator prototype 1 adalah :Dra.Rukiyah,M.Pd Dosen Universitas Sriwijaya. Sebagai validator media dan Mahyumi Rantina,M.Pd Dosen Universitas Sriwijaya. Sebagai validator materi.

Tabel 7 Hasil Validasi Materi

\begin{tabular}{|c|c|c|c|c|}
\hline No & Indikator & No Pernyataan & $\begin{array}{c}\text { Jumlah } \\
\text { Pemyataann }\end{array}$ & $\begin{array}{l}\text { Rekapitulasi } \\
\text { Nilai }\end{array}$ \\
\hline 1 & $\begin{array}{l}\text { Kriteria materi } \\
\text { pada media }\end{array}$ & $1,2,3,4$ & 4 & 14 \\
\hline 2 & $\begin{array}{l}\text { Kesesuain dengan } \\
\text { pembelajaran } \\
\text { anak usia } 5-6 \\
\text { tahun }\end{array}$ & $5,6,7,8$ & 4 & 14 \\
\hline 3 & $\begin{array}{l}\text { Kesesuain dengan } \\
\text { kebutuhan dan } \\
\text { perkembangan } \\
\text { anak usia } 5-6 \\
\text { tahun }\end{array}$ & $9,10,11,12$ & 4 & 15 \\
\hline 4 & Manfaat Media & $13,14,15,16$ & 4 & 15 \\
\hline \multicolumn{3}{|c|}{ Jumlah } & 16 & 59 \\
\hline \multicolumn{3}{|c|}{ Skor Rata-Rata } & \multicolumn{2}{|c|}{3,68} \\
\hline \multicolumn{3}{|c|}{ Kategori } & \multicolumn{2}{|c|}{ Sangat Valid } \\
\hline
\end{tabular}

Pada Tabel 8 dan didapatkan bahwa rata-rata validasi Content/Materi sebesar 3,68 dikategorikan Sangant Valid dinjau dari kriteria materi pada maket sangat baik,Kesesuaian dengan pembelajaran anak usia 5-6 tahun ,kesesuaian dengan kebutuha anak usia 56 tahun dan juga manfaat media yang sudah baik.
Tabel 8 Validasi Media

\begin{tabular}{|c|l|c|c|c|}
\hline No & \multicolumn{1}{|c|}{ Indikator } & No Pemyataan & $\begin{array}{c}\text { Jumlah } \\
\text { Pemyataann }\end{array}$ & $\begin{array}{c}\text { Rekapitulasi } \\
\text { Nilai }\end{array}$ \\
\hline 1 & Pewamaan & $1,2,3,4$ & 4 & 15 \\
\hline 2 & Kemasan & $5,6,7,8$ & 4 & 16 \\
\hline 3 & Pemakaian & $9,10,11,12$ & 4 & 14 \\
\hline 4 & Desain & $13,14,15,16$ & 4 & 16 \\
\hline \multicolumn{3}{|c|}{ Jumlah } & 16 & 61 \\
\hline \multicolumn{2}{|c|}{ Skor Rata-Rata } & 3,81 \\
\hline \multicolumn{2}{|c|}{ Kategori } & Sangat Valid \\
\hline
\end{tabular}

Pada Tabel 8 validasi media didapatkan rata-rata hasil valiadasi sebesar 3,81 (Kategori Sangat valid) ditinjau dari beberapa kategori pewarnaan yang sudah baik kombinasi warna sesuai warna tidak luntur,Kemasan produk maket yang aman tidak tajam sehingga menarik minat anak,lalu kategori Pemakaian media mudah disimpan mudah dapat dibongkar pasang mudah digunakan,dan yang terakhir desain ilustrasi produk maket jelas menarik kuat dan tahan lama.

Tabel hasil 9 Rata-Rata Validasi

\begin{tabular}{|c|c|c|}
\hline No & Validasi & Rekapitulasi Nilai \\
\hline 1 & Content/materi & 3.68 \\
\hline 2 & Desain & 3.81 \\
\hline \multicolumn{2}{|c|}{ Rata-Rata } & $\mathbf{3 , 3 0}$ \\
\hline \multicolumn{2}{|c|}{ Kategori } & Sangat Valid \\
\hline
\end{tabular}

Berdasarkan Tabel 9 didapatkan bahwa rata-rata hasil validasi expert review untuk aspek content/materi maket sebesar 3.68 dikategorikan Sangat valid). dan untuk desain media maket sebesar 3.81 (Kategori Sangat valid) sehingga didapatkan hasil rata-rata validasi ahli untuk media maket sebesar 3,80 dikategorikan sangat valid Dengan demikian media maket berbasis kota palembang ini layak untuk diuji coba. Senada dengan penelitian yang dilakukan oleh Cahyaka (2017) bahwa hasil penilaian media maket yang dilakukukan oleh ahli media sebesar 80,33\% tergolong valid dan layak diuji cobakan. 
Beberapa Komentar dan Saran dari validator komentar dan saran dari validator dapat dilihat Pada tabel 10 berikut ini. Validator

Tabel 10 Komentar Saran

\begin{tabular}{|c|c|l|c|}
\hline No & Validator & \multicolumn{1}{|c|}{ Komentar } & Tanggapan Peneliti \\
\hline 1 & Validator 1 & Cangkupan materi diperluas & Telah Diperbaiki \\
\hline 2 & Validator 2 & $\begin{array}{l}\text {-Wama diubah menjadi } \\
\text { wama emas. } \\
\text {-Ukuran jangan terlalu besar }\end{array}$ & Telah Di Perbaiki \\
\hline
\end{tabular}

\subsubsection{Hasil Tahap One-to one Evaluation}

Setelah dilakukan tahap expert review terhadap protive 1 , selanjutnya dilakukan tahap one-to one evalution yang bertjuan untuk melihat kepratisan protive 1 yang telah divalidasi oleh ahli. Tahap ini melibatkan 3 orang anak dan mereka secara bersamaan menggunakan protive 1 , mereka di observasi oleh peneliti yang bertujuan untuk melihat dan menilai secara langsung aktivitas dan tingkah laku anak terhadap prototive 11

\section{Tabel 11 Data hasil observasi anak Pada tahap One to One}

\begin{tabular}{|c|c|c|c|}
\hline No & Nama & \multicolumn{2}{|c|}{ Indikator } \\
\cline { 3 - 4 } & & $\begin{array}{l}\text { 1.Melakukan proses kerja sesuai denganprosedumya } \\
\text { 2. Melakukan kegiatan yang menunjukkan anak } \\
\text { mampu melakukan permainan Motorik. 3. } \\
\text { Melaksanakan perintah yang lebih kompleks sesuai } \\
\text { dengan aturan yang disampaikan(misal: aturan untuk } \\
\text { melakukan kegiatan memasak ikan). }\end{array}$ \\
\cline { 3 - 4 } & & Skor & Nilai \\
\hline 1 & Aqila & 11 & 91 \\
\hline 2 & Jesica & 11 & 91 \\
\hline 3 & Rafa & 12 & 100 \\
\hline Jumlah & & & 282 \\
\hline Rata-rata & & & $94 \%$ \\
\hline
\end{tabular}

diperoleh Nilai Persentase ratarata hasil observasi anak terhadap penggunaan maket pada tahap one to one evaluation sebesar 94 \% Dikategori Baik Sekali sehingga dapat disimpulkan bahwa penggunaan media maket memiliki kriteria praktis bagi anak.berdasarkan validasi ahli dan observasi anak, Protip 1 direvisis menjadi protipe 2 yang selanjutnya akan diuji coba ke small group evaluation.

Pada tahap small group evaluati,prototipe 2 diuji cobakan kepada 9 orang anak secara kelompok.Pada akhir uji coba small group evaluation, anak diobservasi kembali keaktifitasannya terhadap prototipe 2 yang sedang dikembangkan. Hasil observasi anak terhadap penggunaan Media Maket berbasis kota palembang dapat dilihat pada tabel 12

Tabel 12 Small Group

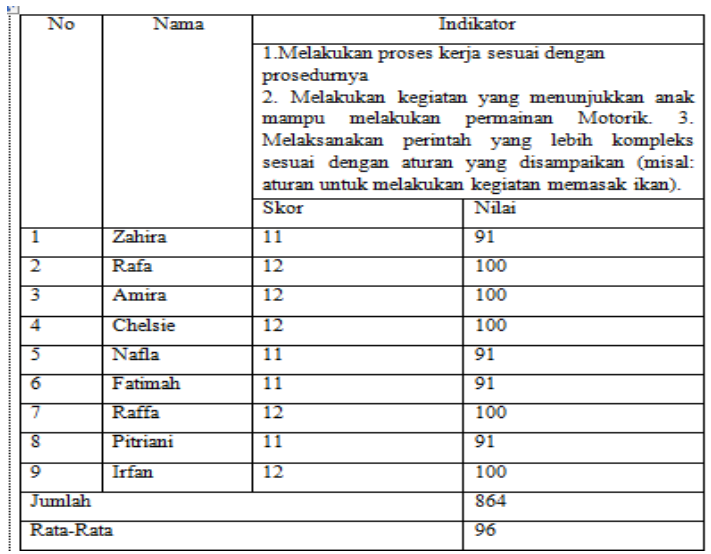

BerdasarkarkanTabel

4.7

diperoleh nilai persantase rata-rata hasil observasi anak terhadap penggunaan media maket pada tahap small group evaluation sebesar $96 \%$ Dikategorikan baik sekali sehingga dapat disimpulkan bahwa penggunaan media maket memiliki kreteria praktis bagia anak.Senada dengan penelitian yang dilakukan oleh putri, eliwatis ,dan Fitri (2014) bahwa hasil observasi maket mendapatkan hasil penilaian 95 dengan demikian produk dapat dikatakan valid dan praktis.

Penelitian pengembangan ini bertujuan untuk mengembangkan media maket berbasis kota palembang untuk anak kelompok B di TK Bhakti Asuhan 1 Palembang.Dalam hal ini penelitian mengembangkan sebuah media maket dengan mengambil tema semester dua. Penelitian ini dilakukan pada tanggal 5 April 2018 hingga 7 April 2018 dengan 
subjek penelitian berupa anak kelompok B di TK Bhakti Asuhan 1 Palembang dan objek penelitian berupa media maket.Penelitian ini menggunakan kombinasi model pengembangan Rowntree dan model evaluasi Formatif tesmer. Model Pengembangan Rowntree terdiri dari tiga tahap, yaitu tahap perencanaan, tahap pengembangan dan tahap evaluasi. Pemilihan model pengembangan Rowntree dalam penelitian ini karena model pengembangan Rowntree merupakan salah satu model yang berorientasi pada produk khususnya untuk memproduksi maket/media. selanjutnya, untuk tahap evaluasi digunakan model evaluasi tesmer yang terdiri dari 5 tahap evaluais digunakan model evaluasi tesmer yang terdiri dari lima tahap, yaitu tahap self evaluation, expert review, one to one,small group.

Penelitian ini, pada evaluasi dilakukan sampai tahap small group dengan tujuan untuk melihat kriteria media pada anak tentang pembelajaran icon kota palembang.Pada Tahap Perencanaan dilakukan analisis kebutuhan dan perkembangan anak.Dalam hal ini Peneliti akan megembangkan media maket berbasis kota palembang karena belum di TK Bhakti Asuhan 1 Palembang dengan merujuk ke kurikulum 2013.

Materi yang diberikan sesuai dengan tema pembelajaran tanah airku maket berbasis kota palembang yang bisa dibongkar pasang adalah memecahkan masalah dikehidupan sehari-hari untuk itu diperlukan sebuah media maket yang menampilkan pembelajaran yang menyenangkan bagi anak sehingga anak lebih tertarik dan dapat dan mempelajari secara mandiri dan media tersebut dapat dibongkar pasang sehingga anak juga dapat bermain sambil berkreasi dimana anak dapat berfikir bagaimana cara mengurutkan serta meyusun bagian bagian maket.Oleh karena itu peneliti mengembangkan media maket berbasis kota palembang dimana bentuk maket yang dibuat yaitu bentuk maket tugu ikan belida yang terdiri dari kemampuan memecahkan masalah yang divisualisasikan kedalam bentuk media yang menarik bagi anak.

Setelah dilakukan tahap perencanaan, selanjutnya peneliti melakukan tahap pengembangan.Tahap Pengembangan terdiri dari dua tahap yaitu pengembangan desain dan produksi prototipe. pada tahap ini juga peneliti menyiapkan perangkat evaluasi. Sebelum digunakan perangkat evaluasi terlebih dahulu dikonsultasikan pada dosen pembeimbing. Hasil Dari Tahap Pengembangan ini adalah prototipe 1 . Maket berbasis kota palembang yang telah dikembangkan kemudian divalidasi oleh para ahli (expert review). Tahap expert review ini bertujuan untuk mengetahui materi dan desain media yang valid. Maket Berbasis Kota Palembang ini validasi ahli content/materi dan desain maket berbasisi kota palembang. Prototipe 1 yang telah didesain kemudian dikonsultasikan dengan ahli lalu divaliadasi oleh ahli.Secara keseluruhan,nilai rata-rata hasil observasi validasi Expert Review pada maket sebesar 3,68 dikategorikan Sangat Valid) sedangkan validasi media sebesar 3,81 dikategorikan Sangat Valid sehingga didapat nilai rata-rata hasil valiadasi ahli untuk maket adalah sebesar 3,80 dikategorikan Sangat Valid.

Dengan demikian maket berbasis kota palembang yang dikembangakan peneliti dapat digunakan pada tahap uji coba selanjutnya. Berdasarkan saran dari validator maka terdapat beberapa revisi prototope 1. Selanjutnya, maket yang telah divalidasi kemudian diuji coba pada tahap one to one evaluation. Tahap one to one evaluation bertujuan untuk melihat kepratisan 1 yang telah di validasi oleh ahli. Tahap ini melibatkan tiga orang anak dan mereka secara bersamaan menggunakan maket berbasis kota 
palembang. Tahap ini guru menjelaskan dan mempraktikan cara menyususn maket bongkar pasang.setelah anak menggunakan protipe 1, peneliti mengobservasi anak pada saat pembelajaran yang bertujuan untuk melihat penilaian mereka terhadap prototipe 1. Nilai persentase rata-rata observasi anak terhdap tahap one to one evaluation pada maket sebesar 86\%dikategorikan Baik Sekali. sehingga dapat disimpulkan bahwa penggunaan maket tergolong praktis. Hasil revisi dari prototipe 1 didapatkan prototipe 2 .

Untuk melihat kepraktisan maket berbasis kota palembang dilakukan uji coba prototipe 2 pada anak dalam tahap small group evaluation. Tahap ini dilaksanakan untuk melihat kepraktisan prototipe 2. Uji coba prototipe 2 ini dilakukan pada 9 orang anak Kelompok B di Tk Bahkti Asuhan 1 Palembang. Tahap ini juga guru yang menjelaskan dan mempraktikan cara menyususn bagian kepingan-kepingan maket. Pada uji coba ditahap small group evaluation , anak diobservasikan kembali.nilai rata-rata persentase hasil observasi tahap small group evaluation sebesar 86\% dikategorikan kategori Baik Sekali.

\section{KESIMPULAN}

Pada penelitian yang telah dilakukan pengembangan media maket berbasis kota Palembang dapat disimpulkan sebagai berikut.Maket yang dikembangkan dinyatakan Sangat Valid berdasarkan hasil Validasi para ahli para ahli (expert review) yang terdiri dari ahli content/materi dan Desain sehingga maket berbasis kota Palembang ini layak digunakan sebagai media untuk pembelajaran. Hal Ini dapat diketahui dari rata-rata hasil expert review sebesar 3,80 dikategorikan Sangat Valid. Untuk menguji kepraktisan maket berbasis kota palembang dilihat dari kemudahan dalam menggunanya.Berdasrkan hasil tahap one-to-one evaluation pada maket sebesar
$86,2 \%$ (Sangat Baik). diperoleh nilai observasi anak terhadap penggunaan maket berbasis kota Palembang. berdasarkan nilai hasil observasi anak terhadap penggunaan maket berbasis kota palembang pada tahap small group evaluation mendapatkan rata-rata $83,3 \%$ (Kategori Baik Sekali) sehingga pada hasil one-to-one dan small group dapat dinyatakan bahwa maket yang dikembangkan telah teruji praktikalitasnya.

DAFTAR PUSTAKA

Afrianti,Waradany,dkk.(2017).

Pengembangan Aplikasi Informasi Wisata di Kota Palembang Berplatfomr android:Jurnal Sistem Informasi.Vol.09.No.01.

Ahmadi, Heri. (2014). Pengembangan Media Pembelajaran Interaktif "Bedah Beruang" Untuk Mengenalkan Konsep Pengurangan Pada Anak Tk Kelompok B. Jurnal Teknologi Pendidikan Dan Pembelajaran 2 (1) $35-48$

Aqib, Zainal. (2016). Model-Model Media dan Strategi Pembelajaran Kontekstual. Bandung:Yrama Widya.

Daryanto.2016.Media Pembelajaran. Yogyakarta:Gava Media.

Enggar, Riyani. (2015). Pengembangan Media Buku Bergambar Tema "Tanah Airku" Untuk Menstimulasi Aspek Bahasa Anak Taman KanakKanak Kelompok B.Jurnal.Fkip Universitas Negri Yogyakarta.

Hartati,Umi.2016.Pengembangan Media Pembelajaran Interaktif "Bedah

Beruang" Untuk Mengenalkan Konsep Pengurangan Pada Anak Tk Kelompok B. Jurnal Pendidikan Anak Usia Dini 6 (2)

Hasnunidah, Neni. (2014). Keterampilan Berfikir Kritis Siswa Smp Pada Pembelajaran Ekosistem Berbasis Kontruktivisme Menggunakan Media Maket.Skrpisi.Universitas lampung 
Istianti, T., Abdillah, F., \& Hamid, S. I. (2018). Model Pembelajaran Perilaku Sosial Kewarganegaraan: Upaya Guru Dalam Memupuk Gotong Royong Sejak Dini. Cakrawala Dini: Jurnal Pendidikan Anak Usia Dini, 9(1), 56-62.

Peraturan Menteri Pendidikan dan Kebudayaan Repulik Indonesia Nomor 146 Tahun 2014 tentang Kurikulum 2013 Pendidikan anak Usia Dini.

Putri, Eliwatis, dkk. (2014). Pengembangan Modul Berbantuan Dengan Pengembangan Media Maket Pada Pembelajaran Biologi Kelas X Sman 2 Batusangkar:Jurnal Pendidikan Mipa. 1( 1).

Qo'niah, Siti. (2017). Pengembangan Media Pembelajaran Maket Konstruksi atap Pada Mata Pelajaran Gambar Konstruksi Bangunan Kelas XI TGB 2 SMK Negri 2:jurnal Kajian Pendidikan Teknik Bangunan. 3( 3).

Rosidah, Ria. (2017). Pengembanagan Buku Cerita matematika Untuk Materi Matematika Untuk Anak kelompok B di Tk Pembina.Jurnal fkip Universitas Sriwijaya.

Sari, Lita Purnama. (2014) Penggunaan Media Maket Untuk Meningkatkan Keterampilan Berbicara Pada Anak Kelompok A Tk Pembina Cawas Tahun Ajaran 2013 Jurnal Fkip Universitas Sebelas Maret.Vol.2.

Satrianawati. (2018). Media Dan Sumber Belajar.Yogyakarta.Cv Budi Utama.

Suciati. (2016). Pengembangan Media Maket Alam Kincapelik (Kincir Air Pembangkit Listrik) Dalam Pembelajaran Tematik Kelas Iv Sd.Jurnal Universitas Malang.

Sudjana, N. (2017). Penilaian Hasil Proses Belajar Mengajar. Bandung: PT Remaja Rosdakarya.

Sugiyono. (2017). Metode Penelitian.Bandung.Alfabeta.Cv.

Sugiyono. (2016). Metodelogi Penelitian dan Pengembangan. Bandung. Alfabeta Cv.
Trianto. (2014). Desain Pengembangan Pembelajaran Tematik Bagi Anak usia Dini Tk/Ra \& Anak kelas Awal $\mathrm{Sd} / /$ MI.Jakarta:Kencana. 